\title{
Fatty acid analysis, cytotoxicity, antimicrobial and antioxidant activities of different extracts of the flowers of Nyctanthes arbor-tristis $\mathbf{L}$.
}

\author{
M. M. Haque ${ }^{1,2 *}$, N. Sultana ${ }^{2}$, S. M. T. Abedin ${ }^{1}$, N. Hossain ${ }^{2}$ and S. E. Kabir ${ }^{1}$ \\ ${ }^{1}$ Department of Chemistry, Jahangirnagar University, Savar, Dhaka-1342, Bangladesh \\ ${ }^{2}$ Bangladesh Council of Scientific and Industrial Research (BCSIR), Dhaka-1205, Bangladesh
}

Received: 15 December 2019

Revised: 21 January 2020

Accepted: 08 July 2020

DOI: 10.3329/bjsir.v55i3.49394

\begin{abstract}
The fatty acid analysis and biological activity of n-hexane, dichloromethane, ethyl acetate and methanol extracts of Nyctanthes arbor-tristis L. flowers are reported. Five fatty acids namely palmitic $(44.15 \%)$, stearic $(19.34 \%)$, arachidic $(15.06 \%)$, behenic $(9.77 \%)$ and lignoceric $(11.69 \%)$ acids were identified. From cytotoxicity test, the $\mathrm{LC}_{50}$ values (the median lethal concentration) for n-hexane, dichloromethane, ethyl acetate and methanol extracts as well as for standard vincristine sulphate were found 7.05, 4.67, 3.14, 5.53 and $0.50 \mu \mathrm{g} / \mathrm{ml}$, respectively. Antibacterial activity results of different extracts were compared with standard antibiotic ciprofloxacin and tetracycline by measuring the zone of inhibition diameter in millimeter. The dichloromethane and ethyl acetate extracts showed significant antibacterial activity. From antioxidant activity test, $\mathrm{IC}_{50}$ values ( $50 \%$ inhibitory concentration) of $n$-hexane, dichloromethane, ethyl acetate, methanol extracts and ascorbic acid were found to be $291.92 \mathrm{mg} / \mathrm{ml}, 45.74 \mu \mathrm{g} / \mathrm{ml}, 21.86 \mu \mathrm{g} / \mathrm{ml}, 64.30 \mu \mathrm{g} / \mathrm{ml}$ and $3.98 \mu \mathrm{g} / \mathrm{ml}$, respectively.
\end{abstract}

Keywords: Nyctanthes arbor-tristis; Cytotoxicity; Antibacterial activity; Antioxidant activity

\section{Introduction}

Medicinal plants have attracted much attention recently for being potent sources of biologically active compounds or substances (Peyvast and Khorsandi, 2007; Miladi and Darnak, 2008; Malik et al., 2012; Ahmad et al., 2014). Day by day the frequency of life-threatening infections has increased worldwide. Many infectious microorganisms are being resistant to synthetic drugs. Resistance to antimicrobial agents is growing in a wide variety of pathogens and multiple drug resistance is becoming common in diverse organisms. This situation leads scientists to discover new antimicrobial substances from various medicinal plants and also isolate active ingredients through extraction, isolation and characterization of their constituents (Chew et al., 2012; Ullah et al., 2013).
Nyctanthes arbor-tristis L. is a well known medicinally important plant of Bangladesh and its neighboring countries. As for the medicinal use, the whole plant is used for treatment of cancer (Kirtikar and Basu, 2002). Flowers of Nyctanthes arbor-tristis L. are carminative, astringent and used in ophthalmic purposes (Rani et al., 2012). Juice of flowers is used as a tonic in preventing graying of hair and hair fall (Girach et al., 1994). Several reports are available in the literature describing the use of the flower extracts of Nyctanthes arbor-tristis L. Antimicrobial activity (Syam et al., 2015), antioxidant and polyphenolic agent identification (Nagavani et al., 2010) and DPPH free radical scavenging capacity of flower extract (Thakur et al., 2017; Jyothi et al., 2018; Bhardwaj and Sharma, 2018) are among many other reports in recent years. But to our knowledge the fatty acid analysis of flower extract has not yet been reported. 
The present research is to study fatty acid compositions in the flowers of Nyctanthes arbor-tristis L. as well as to study cytotoxicity, antibacterial and antioxidant activity of different extracts of the flowers of this plant. Medicinal plants or plant parts are commonly used in herbal industries as medicine and herbal preparations/ formulations in our country. This study will help to develop chemical and biological profiling of the herbal extracts which will ensure herbal identity and improve the quality of plant-based products.

\section{Materials and methods}

\section{General experimental procedures}

All the solvents and chemicals used for this research were analytical reagent grade, procured from E. Merck (Germany), BDH (England), AppliChem (Germany) and Sigma Aldrich (Germany). Gas chromatography analyses were performed with a SHIMADZU 2010 Plus gas chromatograph equipped with a flame ionization detector (FID) and a fused silica (5\% phenyl/95\% polydimethylsiloxane) capillary column (length $30 \mathrm{~m}$, inner diameter $0.25 \mathrm{~mm}$, film thickness $0.25 \mu \mathrm{m}$ ) using hydrogen as carrier gas $(1.0 \mathrm{ml} / \mathrm{min})$. The injector temperature was $250{ }^{\circ} \mathrm{C}$ and the column oven was programmed between $50-220^{\circ} \mathrm{C}$ at $4{ }^{\circ} \mathrm{C} / \mathrm{min}$. The detector (FID) was operated at $260^{\circ} \mathrm{C}$. The absorbance of prepared solutions (extractive or control) of different concentrations for antioxidant activity was performed by using a Parkin Elmer Lambda-25 UV-VIS spectrophotometer (USA). Quartz cells $(1 \mathrm{~cm} \times 1 \mathrm{~cm})$ were used as sample holder to record the spectrum.

Flowers of Nyctanthes arbor-tristis were collected from BCSIR campus, Dhaka, Bangladesh. The flowers were dried, powdered and extracted successively with n-hexane, dichloromethane, ethyl acetate and methanol at room temperature according to the published procedure (Haque et al., 2019). The resulting extracts were filtered, concentrated, dried and stored in a desiccator for use in subsequent experiments.

\section{Identification and quantification of fatty acids}

The esterification of fat was carried out by a modified procedure using trifluoride methanol $\left(\mathrm{BF}_{3}-\mathrm{MeOH}\right)$ complex (Griftin, 1960; Metecalfe and Schmitz, 1961; AOAC, 1984). The n-hexane extract (200 mg) was methylated by heating with $\mathrm{BF}_{3}-\mathrm{CH}_{3} \mathrm{OH}$ reagent $(5 \mathrm{ml})$ for $10 \mathrm{~min}$. Methyl esters of fatty acids were isolated by partitioning between water and n-hexane. The esterified fatty acids were taken for GC analysis.

Fatty acid methyl esters (Sigma-Aldrich) of capric acid, caprilic acid, lauric acid, myristic acid, palmotelic acid, palmitic acid, linolic acid, oleic acid, stearic acid, arachidic acid, behenic acids and lignoceric acid were used as standard for the identification of sample peaks. The fatty acids were identified by comparison of retention times with the standard fatty acids chromatogram. The peak areas were calculated by software of the instrument. The relative percentages of fatty acids were calculated by using the following formula:

Relative $\%$ of individual fatty acid $=$ (Individual area/ Total areas for all fatty acids) $\times 100$

\section{Brine shrimp lethality bioassay}

Brine shrimp lethality bioassay of crude extracts of n-hexane, dichloromethane, ethyl acetate and methanol were screened for cytotoxicity by the Mayer's method (Mayer et al., 1982; McLaughlin et al., 1998). Test samples of $4 \mathrm{mg}$ were dissolved in $200 \mu \mathrm{L}$ of pure dimethylsulfoxide (DMSO) to prepare stock solutions. Then $100 \mu \mathrm{L}$ of stock sample solution was taken in a test tube each containing $5 \mathrm{ml}$ of simulated seawater and 10 shrimp nauplii. The concentration of prepared sample solution in the first test tube was $400 \mu \mathrm{g} / \mathrm{ml}$. Then a series of sample solutions of lower concentrations were prepared by consecutive dilution. In each case $100 \mu \mathrm{L}$ sample was added to each test tube containing $5 \mathrm{ml}$ of brine solution with 10 living nauplii and fresh $100 \mu \mathrm{L}$ DMSO was added into the mother solution. Finally, the prepared sample concentrations in each test tube were $400,200,100,50,25,12.5,6.25,3.125,1.563,0.781$, 0.391 and $0.195 \mu \mathrm{g} / \mathrm{ml}$. After 24 hours, test tubes were inspected using a magnifying glass and the number of survived nauplii of each test tube was counted visually. The mortality percentages of the nauplii at different concentrations were plotted against the logarithm of particular sample concentration to achieve $\mathrm{LC}_{50}$ value (the concentration when $50 \%$ of brine shrimp nauplii died). The $\mathrm{LC}_{50}$ values were calculated by windows Microsoft Excel 2007 software. Standard vincristine sulfate was used as a positive control to compare the results obtained for test samples. 


\section{Antibacterial study}

Antibacterial assay was determined by disc diffusion method (Bauer et al., 1966; Barry, 1980). Four gram-positive bacteria (Bacillus subtilis, Bacillus cereus, Staphylococcus aureus and Enterococcus fecalis) and four gram-negative bacteria (Salmonella typhi, Escherichia coli 12079, Salmonella enteritis and Pseudomonas) were taken for the analysis. Crude extracts of n-hexane, dichloromethane, ethyl acetate and methanol were taken for antimicrobial screening. Standard ciprofloxacin and tetracycline were used as positive control. Each sample and standards were weighed accurately, then dissolved in their required volume of specific solvent (used DMSO for all samples as well as standards). The diluted extracts were applied to sterile discs at a concentration of $400 \mu \mathrm{g} /$ disc. Standard ciprofloxacin and tetracycline containing doses were 5 and $30 \mu \mathrm{g} /$ disc respectively. The sample and control discs were placed gently on the previously marked zones in the agar plates pre-inoculated with test bacteria. Then the plates were incubated at $37{ }^{\circ} \mathrm{C}$ for $24 \mathrm{~h}$. After incubation, the antimicrobial activity for each test material was determined by measuring the diameter of the zone of inhibition in millimeter and compared with the results obtained for positive control.

\section{Antioxidant activity}

The antioxidant activity analysis by DPPH (1, 1-diphenyl2-picrylhydrazyl) free radical scavenging assay test was carried out according to the method reported by Brand-Williams (Brand-Williams et al., 1995).

Ascorbic acid was used as a positive control. The absorbance was measured at $517 \mathrm{~nm}$ against methanol as blank (zero absorbance) by UV-VIS spectrophotometer.

Inhibition of free radical DPPH in percent was calculated as follows:

Inhibition $(\%)=\left[1-\left(\mathrm{ABS}_{\text {sample }} / \mathrm{ABS}_{\text {blank }}\right)\right]$ X 100

Where,

$\mathrm{ABS}_{\text {sample }}=$ the absorbance of particular test sample, and

$\mathrm{ABS}_{\text {blank }}=$ the absorbance of the control reaction (containing all reagents except test sample).

$\mathrm{IC}_{50}$ values were calculated as the concentration of each sample required to give $50 \%$ DPPH radical scavenging

Table I. Fatty acid composition in the flower of Nyctanthes arbor-tristis L.

\begin{tabular}{|c|c|c|c|}
\hline Serial no. & Name of the fatty acid & Area & Relative percentage (\%) \\
\hline 1 & Palmitic acid & 362861 & 44.15 \\
\hline 2 & Stearic acid & 158927 & 19.34 \\
\hline 3 & Arachidic acid & 123773 & 15.06 \\
\hline 4 & Behenic acid & 80312 & 9.77 \\
\hline 5 & Lignoceric acid & 96056 & 11.69 \\
\hline & Total & 821929 & 100 \\
\hline
\end{tabular}




\section{Brine shrimp cytotoxicity test}

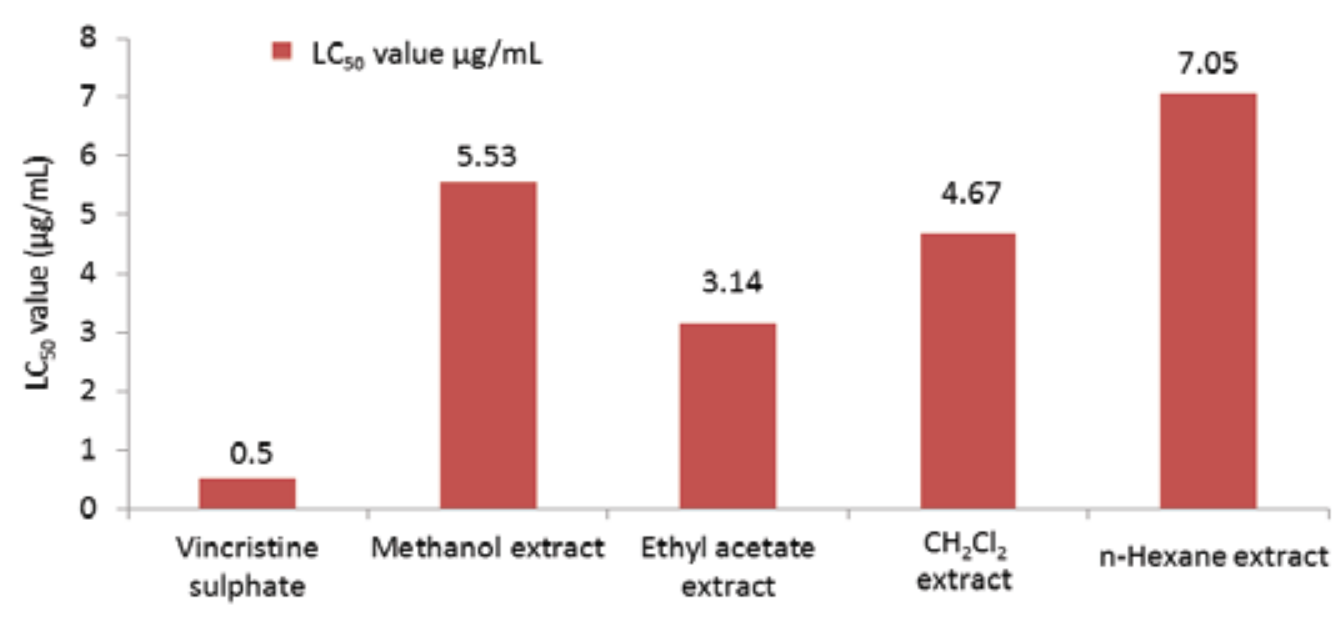

Fig. 1. Cytotoxicity test results $\left(\mathrm{LC}_{50}\right.$ values) of different extracts of Nyctanthes arbor-tristis $\mathrm{L}$. flower

activity from the graph (linear regression curve) by excel 2007 Office software.

\section{Results and discussion}

\section{Fatty acid compositions}

A total of 5 (five) fatty acids was identified as their methyl esters. The relative percentages of the individual acids were found to be (Table I) palmitic acid (44.15\%), stearic acid (19.34\%), arachidic acid (15.06\%), behenic acid $(9.77 \%)$ and lignoceric acid $(11.69 \%)$. The percentage of palmitic acid was the major fatty acid while stearic, arachidic, behenic and lignoceric acids were the minor fatty acids. All fatty acids found in Nyctanthes arbor-tristis L. flower are saturated fatty acids.

\section{Brine shrimp lethality bioassay}

Bioactive compounds (natural or synthetic origin) are almost always toxic to living bodies in higher doses. These compounds are often toxic to the Artemia salina (Brine shrimp) nauplii. Thus, in vivo lethality to brine shrimp nauplii can be used as a simple, rapid and favorable monitor for screening and fractionation in the discovery of new bioactive natural products (McLaughlin et al., 1998). All the extracts showed significant cytotoxicity towards brine shrimps within $24 \mathrm{~h}$. The results of $\mathrm{LC}_{50}$ values for different extracts and standard vincristine sulfate (positive control) are shown in Fig. 1. The $\mathrm{LC}_{50}$ values for $\mathrm{n}$-hexane, dichloromethane, ethyl acetate and methanol extracts of Nyctanthes arbor-tristis L. flower as well as for standard vincristine sulphate were found to be $7.05,4.67,3.14,5.53$ and $0.50 \mu \mathrm{g} / \mathrm{ml}$ respectively. The best cytotoxicity was found for the ethyl acetate extract (3.14 $\mu \mathrm{g} / \mathrm{ml}$ ). In comparison to the positive control (standard vincristine sulfate), it appeared that all the test samples were lethal to brine shrimp nauplii. However, ethyl acetate, dichloromethane and methanol extracts demonstrated more potent activity in brine shrimp lethality bioassay than n-hexane extract.

The brine shrimp lethality bioassay test is considered to be very useful in determining various biological activities such as pesticidal, phototoxic, trypanocidal, cytotoxic, ion regulation and enzyme inhibition activities (Ramamoorthy et al., 2012). So the results of different extracts suggested that they might have one or more of this kind of biological activities.

\section{Antibacterial study}

The results of antibacterial study of different extracts were compared with that of standard antibiotic ciprofloxacin and tetracycline by measuring the zone of inhibition diameter in millimeter. The results are presented in Table II. The 
Table II. Antibacterial activity of different extracts of the flowers of Nyctanthes arbor-tristis L. and standards

\begin{tabular}{|c|c|c|c|c|c|c|}
\hline \multirow{3}{*}{ Name of the bacteria } & \multicolumn{6}{|c|}{ Zone of inhibition in $\mathrm{mm}$} \\
\hline & n-Hexane & $\mathrm{CH}_{2} \mathrm{Cl}_{2}$ & $\begin{array}{c}\text { Ethyl } \\
\text { acetate }\end{array}$ & Methanol & $\mathrm{CP}$ & $\mathrm{TE}$ \\
\hline & \multicolumn{4}{|c|}{$400 \mu \mathrm{g} / \mathrm{disc}$} & $5 \mu \mathrm{g} / \mathrm{disc}$ & $30 \mu \mathrm{g} / \mathrm{disc}$ \\
\hline \multicolumn{7}{|c|}{ Gram -positive bacteria } \\
\hline Bacillus subtilis & 7 & 9 & 11 & 6 & 27 & 24 \\
\hline Bacillus cereus & - & 6 & 15 & 9 & 29 & 21 \\
\hline Staphylococcus aureus & - & 10 & 10 & - & 25 & 26 \\
\hline Enterococcus fecalis & - & - & - & - & 21 & 16 \\
\hline \multicolumn{7}{|c|}{ Gram -negative bacteria } \\
\hline Salmonella typhi & - & - & - & - & 35 & 25 \\
\hline Escherichia coli 12079 & - & - & 7 & - & 25 & 9 \\
\hline Salmonella enteritis & - & - & - & - & 39 & 23 \\
\hline Pseudomonas & - & 6 & 8 & 10 & 29 & 16 \\
\hline
\end{tabular}

$\mathrm{CH}_{2} \mathrm{Cl}_{2}$ : Dichloromethane, $\mathrm{CP}$ : Standard ciprofloxacin, TE: Standard tetracycline

dichloromethane and ethyl acetate extracts showed significant antimicrobial activity against gram-positive bacteria B. subtilies, B. cereus, S. aureus and gram-negative bacteria Pseudomonas.

\section{Antioxidant activity}

The summarized results of free radical scavenging activity for different extracts along with the $\mathrm{IC}_{50}$ value of ascorbic acid (used as positive control) are presented in Table III. The $\mathrm{IC}_{50}$ values of n-hexane, dichloromethane, ethyl acetate and methanol extracts as well as ascorbic acid were found to be $291.92 \mathrm{mg} / \mathrm{ml}, 45.74 \mu \mathrm{g} / \mathrm{ml}, 21.86 \mu \mathrm{g} / \mathrm{ml}, 64.30 \mu \mathrm{g} / \mathrm{ml}$ and $3.98 \mu \mathrm{g} / \mathrm{ml}$, respectively. The dichloromethane, ethyl acetate and methanol extracts showed significant free radical scavenging activity. Commercially available synthetic antioxidants such as butylated hydroxy anisole (BHA) and butylated hydroxy toluene (BHT) are widely used but these may possess toxic side effects on human health (Albayrak and Aksoy, 2013). So, researchers gave their attention towards the natural antioxidants, especially collected from plants. In plant, polyphenolics (e.g. tannins and flavonoids) are the active ingredients which are responsible for their antioxidant effect (Tanabe et al., 2002; Albayrak and Aksoy, 2013; Bendary et al., 2013). Previous phytochemical screening for the flowers of Nyctanthes arbor-tristis L. showed the presence of tannins, flavonoids, carbohydrates, 
Table III. IC $_{50}$ values of DPPH free radical scavenging activity obtained for different crude extracts of Nyctanthes arbor-tristis L. flowers

\begin{tabular}{cc}
\hline Sample & IC $_{50}$ value \\
\hline n-Hexane extract & $291.92 \mathrm{mg} / \mathrm{ml}$ \\
\hline Dichloromethane extract & $45.74 \mu \mathrm{g} / \mathrm{ml}$ \\
\hline Ethyl acetate extract & $21.86 \mu \mathrm{g} / \mathrm{ml}$ \\
\hline Methanol extract & $64.30 \mu \mathrm{g} / \mathrm{ml}$ \\
\hline Ascorbic acid (positive control) & $3.98 \mu \mathrm{g} / \mathrm{ml}$ \\
\hline
\end{tabular}

glycosides, cardiac glycosides, reducing sugar, saponins, terpenoids and steroids (Haque et al., 2019). So, the present study indicates that the flower of Nyctanthes arbor-tristis L. has the potential to be a good source of natural antioxidants.

\section{Conclusions}

The flowers of Nyctanthes arbor-tristis L. contain saturated fatty acids such as palmitic, stearic, arachidic, behenic and lignoceric acid. From the cytotoxicity test, the best cytotoxicity was found for the ethyl acetate extract $\left(\mathrm{LC}_{50}\right.$ value $=3.14 \mu \mathrm{g} / \mathrm{ml}$ ). In comparison with the positive control (standard vincristine sulfate), it is evident that all the test samples were lethal to brine shrimp nauplii. The results of antimicrobial activity of n-hexane, dichloromethane, ethyl acetate and methanol extracts of the flower were compared with standard antibiotic ciprofloxacin and tetracycline by measuring the zone of inhibition diameter in millimeter. The dicholoromethane and ethyl acetate extracts showed significant antimicrobial activity against gram positive bacteria $B$. subtilies, $B$. cereus, $S$. aureus and gram negative bacteria Pseudomonas. The dichloromethane, ethyl acetate and methanol extracts showed significant DPPH free radical scavenging activity. This study demonstrates that the flowers of the plant Nyctanthes arbor-tristis L. grown in Bangladesh have considerable importance as herbal medicine as well as have natural antioxidants.

\section{References}

Adamu HM, Abayeh OJ, Agho MO, Abdullahi AL, Uba A and Dukku HU (2005), An ethnobotanical survey of Bauchi state herbal plants and their antimicrobial activity, J. Ethnopharmacol. 99(1): 1-4. DOI: org/10.1016/j.jep.2004.12.025

Alo MN, Anyim C, Igwe JC, Elom M and Uchenna DS (2012), Antibacterial activity of water, ethanol and methanol extracts of Ocimum gratissimum, Vernonia amygdalina and Aframomum melegueta, Adv. Appl. Sci. Res. 3(2): 844-848.

Ahmad S, Bashir MT, Khaliq FH, Mannan A and Mukhtar MF (2014), Antimicrobial and toxicological studies of Ochthochloa compressa plant, Pakistan J. Pharma. Sci. 27(5):1209-1213.

Albayrak S and Aksoy A (2013), Biological activities of Wiedemannia multifida (Linnaeus) Benthum and Wiedemannia orientalis Fisch. \& Mey, Asian Pac. J. Trop. Biomed. 3(3): 196-201.

AOAC (1984), Association of Official Analytical Chemists. Official Methods of Analysis, $14^{\text {th }}$ Ed., Arlington, VA.

Barry AL (1980), Procedures for testing antimicrobial agents in agar media In: Antibiotics in laboratory medicines, William and Wilkins Co., Baltimore, USA, pp 1-122.

Bauer AW, Kirby WMM, Sherris JC and Turck M (1966), Antibiotic susceptibility testing by a standardized single disc method, Am. J. Clin. Pathol. 45: 493-496.

Bendary E, Francis RR, Ali HMG, Sarwat MI and Hady SEI (2013), Antioxidant and structure-activity relationships (SARs) of phenolics and anilines compounds, Ann. 
Agric. Sci. 58(2): 173-181. DOI: org/10.1016/j. aoas.2013.07.002

Bhardwaj A and Sharma S (2018), Phytochemical and Antibacterial Studies on Methanolic Flower Extracts of Nyctanthes arbor-tristis L., J. Applicable. Chem. 7(4): 958-963.

Brand-Williams W, Cuvelier ME and Berset C (1995), Use of free radical method to evaluate antioxidant activity, Lebens-Wiss Technol. 28: 25-30.

Chew AL, Jessica JJA and Sasidharam S (2012), Antioxydent and antibacterial activity of different parts of Leucas aspera, Asian Pac. J. Trop. Biomed. 2(3): 176-180.

Ghani A (2003), Medicinal Plants of Bangladesh with Chemical Constituents and Uses, $2^{\text {nd }}$ Ed., Asiatic Society of Bangladesh, Dhaka-1000, Bangladesh), $p$ 320.

Girach RD, Aminuddin SA, Siddiqui PA and Khan SA (1994), Ethnomedicinal studies on Harsingar (Nyctanthes arbortristis L.: A less known medicinal plant in Unani Medicine, Hamdard Med. 37(2): 60-66.

Griftin RC (1960), A. M. S. M. Technical Method of Analysis, $2^{\text {nd }}$ Ed., Mc Graw-Hill Co. Inc., New York and London, p 299.

Peyvast G and Khorsandi Z (2007), Antibacterial Activity of the Broad Bean Extracts on Resistant Bacteria, Pak. J. Biol. Sci. 10: 398-402. DOI: 10.3923/pjbs. 2007.398.402

Haque MM, Sultana N, Abedin SMT and Kabir SE (2019), Phytochemical screening and determination of minerals and heavy metals in the flowers of Nyctanthes arbortristis Linn., Bangladesh J. Sci. Ind. Res. 54(4): 321-328.

Jyothi VM, Bhargav E, Kumar PK, Gowd PK and Pavan SR (2018), Evaluation of antioxidant and anthelmintic activity of methanolic flower extract of Nyctanthes arbor-tristis Linn, Int. J. Res. Pharm. Sci. 9(1):78-81.

Kivanc M (1997), Antimicrobial activity of fresh plant juice on the growth of bacteria and yeasts, J. Qafqaz Uni. 1: 27-35.
Kirtikar KR and Basu BD (2002), Indian Medicinal plants, Sri Satguru Publications, New Delhi VII: 2110-2113. DOI: org/10.1080/13880200600591972

Malik CP, Garg P, Singh Y and Grover S (2012), Medicinal uses, chemical constituents and micro propagation of three potential medicinal plants, Int. J. Life Sci. and Pharma. Res. 2(3): 57-76.

Mayer BN, Ferrigni NR, Putnam JE, Jacobsen LB, Nichols DE and Mc Langhlin JL (1982), Brine shrimp: A convenient bioassay for active plant constituents, Planta Medica 45: 31-34.

McLaughlin JL, Rogers LL and Anderson JE (1998), The use of biological assays to evaluate botanicals, Drug Inf. $J$. 32: 513-524.

Metecalfe LD and Schmitz AA (1961), The rapid preparation of fatty acideEsters for gas chromatographic analysis, Anal. Chem. 33(3): 363-364.

Miladi S and Darnak M (2008), In vitro Antioxidant activities of Aloe vera leaf skin extract, J. Soc. Chim. Tunisie 10: 101-109.

Malik CP, Poonam G, Singh Y and Grover S (2012), Medicinal uses, chemical constituents and micro propagation of three potential medicinal plants, Int. J. Life Sci. Pharma. Res. 2: 3.

Nagavani V, Raghava RKV, Kiran RC and Raghava RT (2010), In-vitro screening of Nyctanthes arbor-tristis flowers for antioxidant activity and identification of polyphenols by RP-HPLC, Pharmacology online 2: 57-78.

Peyvast G and Khorsandi Z (2007), Antibacterial activity of the broad bean extracts on resistant bacteria, Pak. $J$. Biol. Sci. 10: 398-402.

Ramamoorthy PKT, Shetty RHL, Devidas S, Mudduraj VT and Vinayaka KS (2012), Antifungal and cytotoxic activity of Everniastrum cirrhatum (Fr.) Hale., Chiang Mai. J. Sci. 39(1): 76-83.

Rani C, Chawla S, Mangal M, Mangal AK, Kajla S and Dhawan AK (2012), Nyctanthes arbor-tristis Linn. (Night Jasmine): A sacred ornamental plant with immense medicinal potentials, Indian J. tradit. knowl. 11(3): 427-435. 
Syam SK, Anudeep M, Ramana CV and Bhaskar C (2015), Screening of antimicrobial activity of flower extracts on human bacterial pathogens, J. Pharmacogn. Phytochem. 3(6): 153-156.

Tanabe H, Yoshiad M and Tomita N (2002), Comparison of the antioxidant activities of 22 commonly used herbs and spices on the lipid oxidation of pork meat, Anim. Sci. J. 73: 389-393.

Thakur MK and Jaiswal P (2017), The investigation on total phenolic content and in vitro antioxidant potential of different plant parts of Nyctanthes arbor-tristis (night jasmine), 8(8): 3547-3551.

Ullah MO, Haque M, Urmi KF, Zulfiker AHM, Anita ES, Begum M and Hamid K (2013), Anti-bacterial activity and brine shrimp lethality bioassay of methanolic extracts of fourteen different edible vegetables from Bangladesh, Asian Pac. J. Trop. Biomed., 3(1): 1-7. DOI: org/10.1016/S2221-1691(13)60015-5 